\title{
No More Cuts: The Curious Fate of Self-Mutilation in Its Development
}

\author{
Zhabiz Kazeminezhad M.D. (PGY4) \\ Zhabiz.Kazeminezhad@mail.tju.edu \\ Salman Akhtar M.D. \\ salman.akhtar@jefferson.edu
}

Follow this and additional works at: https://jdc.jefferson.edu/jeffjpsychiatry

Part of the Psychiatry Commons

Let us know how access to this document benefits you

\author{
Recommended Citation \\ Kazeminezhad, Zhabiz M.D. (PGY4) and Akhtar, Salman M.D. (2006) "No More Cuts: The Curious Fate of \\ Self-Mutilation in Its Development," Jefferson Journal of Psychiatry. Vol. 20 : Iss. 1 , Article 5. \\ DOI: https://doi.org/10.29046/JJP.020.1.004 \\ Available at: https://jdc.jefferson.edu/jeffjpsychiatry/vol20/iss1/5
}

This Article is brought to you for free and open access by the Jefferson Digital Commons. The Jefferson Digital Commons is a service of Thomas Jefferson University's Center for Teaching and Learning (CTL). The Commons is a showcase for Jefferson books and journals, peer-reviewed scholarly publications, unique historical collections from the University archives, and teaching tools. The Jefferson Digital Commons allows researchers and interested readers anywhere in the world to learn about and keep up to date with Jefferson scholarship. This article has been accepted for inclusion in Jefferson Journal of Psychiatry by an authorized administrator of the Jefferson Digital Commons. For more information, please contact: JeffersonDigitalCommons@jefferson.edu. 


\section{No More Cuts: The Curious Fate of Self- Mutilation in Its Development}

Zhabiz Kazeminezhad, M.D. (PGY4), Salman Akhtar, M.D.

\section{ABSTRACT}

In this article, we present descriptions of four young women with relatively severe personality disorders. All four were in psychodynamic psychotherapy and all had the symptom of self-cutting. During their treatment, it became evident that their self-cutting had undergone a transformation and a new symptom had appeared in its place. In three, self-cutting was substituted by behaviors that we might call "cutting equivalents" and, in the fourth, by an enhanced self-reflective attitude and by journal-writing. We suggest that symptom-replacement for self-cutting may be common in its developmental course or in its course as it becomes influenced by psychotherapy, and that the replacement is sometimes, perhaps often, salutary.

Approaching severe personality disorders psychodynamically has its pros and cons (1-3). On the one hand, it provides a deeper and more specific understanding of the patient, one in which his or her symptoms are seen as intricately bound with constitutional givens, early childhood experiences, and unconscious fantasies. On the other hand, if symptoms are end-products of a 'trauma-fantasy-wish-defense' sequence, any effort aimed simply at symptom-reduction is conceptually suspect and has practical risk. Psychodynamic models of etiology compel the prediction that removing a manifest disturbance might be undesirable, if the underlying issues responsible for it remain unresolved. This consideration acquires greater significance in cases of severe personality disorders (e.g., borderline, schizoid, antisocial, paranoid), which in some instances appear nearly intractable. The best outcome could be that a new, less toxic symptom replaces the older, more toxic one. Of course, if the former takes sublimatory or even "pseudo-sublimatory" form (1), the outcome can be regarded as not bad after all. 


\section{CASE REPORTS}

\section{Case 1}

Inez is a 24-year-old nursing student with a history of self-cutting that began at age sixteen, dwindled around age eighteen, and stopped completely by age twentyone. The onset of cutting coincided with her family's moving in with her new step-father. Inez felt she never belonged in that house and was like an unwanted guest. She cut herself when the feeling of being unwanted mounted and became unbearable. The urge to cut was more frequent, but she was able to restrict the act to once a month for fear of getting caught.

Inez was born to adolescent parents of different racial origins who were forced into a marriage because of the pregnancy. Inez's mother soon began an extramarital affair with a man who would later became Inez's stepfather; the parents divorced when she was twelve. Inez was aware of the infidelity, for her mother often had taken her to the house of the mother's lover before the divorce. She often had told Inez, from the latter's early childhood, that Inez was unwanted and the cause of her mother's unhappiness. Whenever they were separated, Inez found herself afraid that her mother would never return.

Inez began to work in a tattoo parlor at age eighteen. As an employee, she was able to get tattoos for free and often took advantage of this perk. Although she said that the pain of the needles bothered her, she found great pleasure in receiving the tattoos. She discovered even more pleasure in displaying them on her body. Interestingly, the self-cutting decreased soon after she began working in the tattoo parlor. Within two years, she had stopped cutting herself altogether, although she continued to obtain new tattoos regularly.

\section{Case 2}

Emily is a 23-year-old graduate student with a history of self-cutting that began at the age of fourteen and ended at eighteen. She began cutting herself soon after the onset of her menses, which she experienced as traumatic. Mostly she cut on her arms and forearms, but after her cutting was discovered by her friends she began cutting on her belly and thighs instead. Cutting relieved the tension that would follow on an argument with her mother. During childhood and adolescence Emily believed that her mother did not love her. Frequent, heated arguments took place, during which Emily would tell her mother that she hated her.

Emily had been born into a working class Catholic family that had traditional views regarding household gender-roles. Beginning at age ten, she was expected to begin preparing dinner before her parents came home; two older brothers had no such responsibilities. Because of this difference in treatment, she often felt that her 
mother did not love her as much as she loved her brothers. She did not want to grow up to be a woman. Menarche was quite disturbing to her and was soon followed by the onset of self-cutting.

The cessation of cutting at eighteen seemed related to substitution of masturbation three times daily, a habit that continues to the present. Much like the self-mutilation of her adolescence, Emily considers the masturbation to be a source of tension release. During masturbation, she often fantasizes about being raped or otherwise forced into sexual activity: it is as if the tormented soothing of cutting had been replaced by the sadomasochistic erotic fantasy.

\section{Case 3}

June is a 29-year-old, unemployed African-American woman with a long history of self-cutting. Cutting began at age eight soon after being sexually abused by a friend of her parents. The sexual molestation occurred many times but spontaneously ceased after about a year. June would cut herself immediately after an episode of molestation because she felt she needed to, literally and physically, feel her emotional pain: “Talking about it wasn't intense enough.” Cutting lessened in adolescence when she began to act out in school, skipping classes, fighting with classmates, and having indiscriminate sexual encounters with boys. After high school, June eventually became monogamous and stopped self-cutting. About five years later, it started again when a male companion had become physically abusive towards her. After leaving that relationship, the behavior again ceased. However, since then, June finds that affectionate sexual play is not satisfactory to her. During sex, she likes to pretend that she is being beaten or raped, a form of selfabuse that is possibly akin to cutting.

Her parents were intravenous drug abusers who lived together at the time she was born. Soon after, the father contracted HIV and eventually passed it on to the mother. The latter was severely verbally abusive to June. The father has since died. Her relationship with her mother remains ambivalent. To date, whenever mother and daughter argue, June finds that she wants to scratch herself. Blood is not drawn, nor is that her intent.

June's self-cutting relieved tension, as it almost always followed the mother's verbal abuse. It also seemed to be related to an inability to feel satiated emotionally by verbalizing pain. Over time, she replaced cutting herself with acts of physical aggression toward others, sexual promiscuity, and masochistic sexual fantasies. 


\section{Case 4}

Rebecca is a highly intelligent 22-year-old African-American college student with a record of academic excellence dating back to childhood. She also has a history of self-cutting that began at age twelve and ended at fifteen. She recalls that the impetus for this behavior began with reading a magazine article written about a young woman who had had experiences much like her own and had found emotional release through the act of self-cutting. At a younger age, Rebecca had experienced many events that left her anxious and tense. First, she had been sexually abused by her grandmother as a young child. Next, her parents divorced when she was twelve. After the divorce, her father made no attempt to contact the family again. Rebecca had been closest to her father; he had given much love, attention, and intellectual encouragement.

She found the razor cutting across her skin particularly pleasurable. She also enjoyed watching blood being expressed from the site of the cut. As she discovered such pleasures, she cut herself habitually whenever she was sad, especially if the sadness was accompanied by an urge to cry. Cutting decreased when she began drinking alcohol, but did not stop until age fifteen. Several factors seem responsible for its cessation. She was discovered by family members, who shamed her for her behavior. She also began writing in a journal about her personal experiences and mental pain. Journal writing became an increasing part of her personal life. During these years, whenever she felt the urge to cut, she would go to the bathroom and intently look at the collection of used and bloodied razors; this substituted, she reported, for the literal act of self-cutting.

\section{DISCUSSION}

A symptom neither arises nor is resolved independently of other conscious and unconscious aspects of the patient's mind and the relation between the patient and the therapist. With such proviso, we want to assert that all four patients presented here demonstrate the phenomenon of symptom-replacement. Self-cutting is replaced by receiving tattoos (Inez), sadomasochistic sexual fantasies (Emily), fighting and provocative role-playing during sex (June), and wistfully looking at bloodied razors (Rebecca). An explicit form of self-mutilation is thus transformed into its "aim-inhibited" versions (4). Yet important differences in the four cases can be discerned. Inez, the patient with the most traumatic background, replaced self-cutting by another assault on her body, tattooing. Emily and June channeled self-destructive propensities away from body into mental life, binding their masochism with libido to create erotic sadomasochistic fantasies. Rebecca showed a mixed outcome. On the one hand, masochism moved from body to mind

Jefferson Journal of Psychiatry, Volume 20, Number 1

ISSN 1935-0783

(C) 2006 by the authors

On the Web: jdc.jefferson.edu/jeffjpsychiatry 
(although unerotically). On the other hand, she began to write about the internal distress that had given rise to self-cutting in the first place, showing ego growth and an adaptation akin to sublimation.

The difference in the outcome of self-cutting in these patients is multiplydetermined (5), just the way the symptoms themselves were. Three variables readily come to mind. First is the intensity of childhood trauma. Second is the degree of constitutional resilience, present in one instance in the form of high intelligence. The third is the presence of a reasonably sustained good object relationship during childhood. Among our patients, the one most traumatized could only advance from a naked form of violence against her body to becoming tattooed. On the other end of the spectrum is the patient who had received much love from her father in early childhood and also had high intelligence; she went from cutting to merely looking at razors, also making journal entries about her anguish that, in turn, paved the way to deeper psychotherapy. The outcomes and predisposing factors for the other two patients belong somewhere in between these two extremes.

Such observations suggest that symptom-replacement might be a frequent occurrence during the course of development. If so, a number of factors seem responsible for such an occurrence. With growth, the body changes and so do its psychological meanings. Newer fantasies arise, ego grows, and, in the throes of adolescence, super-ego becomes more abstract and softened (6). Greater life experience provides trials for identifications and realignment of ideals. All this results in changing symptomotology. Depending on the balance of libido versus aggression in the psychic economy, a symptom can become better or worse or be replaced by a parallel symptom.

And symptom-replacement can occur as a result of psychotherapy too, of course, especially in resident-run clinics, where patients derive psychotherapeutic gains largely from ego support, survival of the therapist's containing capacities (7), and inexact interpretations (8). Indeed, the emergence of a milder symptom in place of a more disturbing one might even be a cause of celebration. This has technical significance: when the emergence of a new, but less disturbing, phenomenon can be correlated with the subsiding of a parallel, more severe symptom, the technical approach should not center upon deconstruction-interpretation. Instead, affirmative interventions and provision of ego support for the new compromise formation should be the centerpiece of the therapeutic strategy (9).

Regardless of its context, whether developmental or in psychotherapy, symptom-replacement in regards to self-mutilation appears to be a frequent and often salutary occurrence. Keep in mind, however, the data we present here is limited. As a result, our hypotheses and speculations must be regarded as tentative.

Jefferson Journal of Psychiatry, Volume 20, Number 1

ISSN 1935-0783

(C) 2006 by the authors

On the Web: jdc.jefferson.edu/jeffjpsychiatry 


\section{SOURCE INFORMATION}

From the Department of Psychiatry and Human Behavior, Thomas Jefferson University Hospital, Philadelphia. Direct inquiries to Dr. Kazeminezhad at zhabiz.kazeminezhad@mail.tju.edu

\section{REFERENCES}

1. Kernberg OF (1975). Borderline Conditions and Pathological Narcissism. New York: Jason Aronson.

2. Adler G (1985). Borderline Psychopathology and Its Treatment. New York: Jason Aronson.

3. Akhtar S (1992). Broken Structures: Severe Personality Disorders and Their Treatment. Northvale, NJ: Jason Aronson.

4. Freud S (1915). Instincts and Vicissitudes. Standard Edition 14:117-140.

5. Waelder R. The principle of multiple function: observations on multiple determination. Psychoanal Q 1936; 5: 45-62

6. Jacobson E (1964. The Self and the Object World. New York: International Universities Press.

7. Winnicott DW (1965). Ego integration in child development. In The Maturational Processes and the Facilitating Environment, pp 56-64. New York: International University Press.

8. Glover E. The therapeutic effect of inexact interpretation. Int J Psychoanal 1931; 12:397-415

9. Killingmo B. Conflict and deficit: implications for technique. Int J Psychoanal 1989; 70:65-79 